\title{
Verdade Real e a Impossibilidade de Condenação após Manifestação do Ministério Público por Absolvição
}

\author{
Substantial Truth and the Impossibility of Conviction after \\ Manifestation of the Public Prosecutor's Office for Acquittal
}

Rafael de Deus Garcia ${ }^{1}$

Universidade Federal de Lavras - Lavras/MG

rafaeldedeusgarcia@gmail.com

lattes.cnpq.br/4789803970148615

c) orcid.org/0000-0001-7985-521X

Resumo: Este artigo defende a tese de que a condenação de um acusado apósmanifestaçãodeabsolviçãopeloMinistérioPúblicoemsededealegações finais ofende não somente o princípio acusatório, como também os princípios do contraditório e da ampla defesa. Considerando, no entanto, já haver avançado debate doutrinário acerca da constitucionalidade do artigo 385 do Código de Processo Penal, que trata as alegações finais do MP como mero parecer e que faculta ao juiz condenar o réu mesmo quando a instância acusadora pede a absolvição, este artigo tem a intenção de contribuir para a questão demonstrando que essa possibilidade legal prevista no art. 385 só é possível tendo-se por pressuposto o princípio da verdade real, insustentável tanto do ponto de vista epistemológico quanto político-jurídico. Fato é que o princípio acusatório veda ao juízo substituir a acusação quando esta abandona qualquer narrativa processual acusatória capaz de sustentar eventual condenação.

Palavras-chave: Artigo 385 do CPP; Verdade real; Absolvição; Ministério Público; Contraditório.

ABSTRACT: This paper defends the thesis that the criminal conviction of an accused after a plea of acquittal by the Public Prosecutor's Office in final arguments

1 Mestre e graduado em Direito pela Universidade de Brasília. Professor de Direito Penal e de Processo Penal na Universidade Federal de Lavras. 
offends not only the accusatory principle, but also the right to an adversarial process. It is known that we already have an advanced debate on the constitutionality of article 385 of the Criminal Procedure Code, which treats the MP's final allegations as mere opinion and which allows the judge to convict the defendant even when the prosecutor requests the acquittal, so this article intends to contribute to the issue by demonstrating that this legal possibility has on its ground the substantial truth principle, unsustainable both from the epistemological and the political-juridical point of view. It is a fact that the accusatory principle prohibits the judge from replacing the accusation when it abandons any accusatory narrative capable of sustaining any conviction.

Keywords: Article 385; Substantial truth; Acquittal; Public ministry; Adversarial System.

SumÁRıo: Introduçã o; 1. Princípio Acusatório e o actum trium personarum; 2. Os limites do pedido de condenação na denúncia e a importância das alegações finais; 3. A verdade real como pressuposto epistemológico para a autonomia narrativa do juiz; Considerações Finais; Referências.

\section{INTRODUÇÃO}

Este artigo defende a tese de que a condenação de um acusado após a manifestação ministerial para absolvê-lo ofende o princípio acusatório, previsto na Constituição Federal de 1988 em seu art. 129, I. Essa possibilidade legal é prevista no artigo 385 do Código de Processo Penal $^{2}$, que faculta ao juiz proferir sentença condenatória mesmo quando o Ministério Público tenha se manifestado pela absolvição. Assim, defende-se que o referido dispositivo não foi recepcionado pela $\mathrm{CF} / 88$. Além disso, entende-se que essa possibilidade acarreta a violação do princípio do contraditório e da ampla defesa, uma vez que o juiz, ao

2 No Código de Processo Penal Militar (CPPM), tem-se no art. 437, b, equivalente ao art. 385 do CPP, de modo que a mesma crítica feita neste trabalho igualmente se aplica a esse dispositivo. 
condenar após as partes coadunarem entendimento sobre a absolvição, surpreende a defesa com narrativa inédita no processo.

Embora o debate proposto já se encontra relativamente avançado na doutrina processual penal, o artigo se justifica por apontar a incoerência do referido dispositivo no âmbito epistemológico, vez que decorre diretamente do princípio da verdade real. É justamente a invocação do princípio da verdade real que permite ao juízo transcender às partes do processo e desenvolver tese autônoma e inédita no processo. Assim, mais do que mero parecer, as alegações finais do MP devem ser consideradas como momento de confirmação da pretensão acusatória, pressuposto para a pretensão punitiva estatal.

A impossibilidade de condenação quando o acusador opina pela absolvição decorre não só da força normativa do art. 129, I, da CF/88, como também da posição de garante e de desinteressado imparcial do juiz, elementos típicos do modelo acusatório de processo penal.

O primeiro item do artigo versa sobre o princípio acusatório e o actum trium personarum, fazendo-se também uma distinção dos modelos acusatório e inquisitório, especialmente a partir da compreensão dogmática de Luigi Ferrajoli.

No segundo item, o artigo se preocupa em argumentar acerca da precariedade do pedido de condenação inserido na denúncia. Além de ser elemento dispensável e não previsto nas exigências do art. 41 do CPP, eventual pedido de condenação na denúncia somente se completa quando, em alegações finais, o Ministério Público confirma a pretensão acusatória, momento em que apresenta narrativa capaz de condenar o acusado.

Em um terceiro momento, talvez o principal deste artigo, demonstra-se como o princípio da verdade real se faz presente quando há invocação do art. 385 do CPP. Busca-se demonstrar a falida epistemologia que sustenta o princípio da verdade real e de como ele pode dar azo a uma política criminal e judicial de natureza inquisitorial e autoritária.

É justamente com base no princípio da verdade real que o juiz permite-se invocar o art. 385, fazendo aparecer no processo penal uma terceira parte, parcial e interessada, evidenciada na construção de uma narrativa processual autônoma e inédita no processo, estranha à acusação e à defesa. 


\section{Princí́pio Acusatório e o actum triUm PeRsonarum}

Afrânio da Silva Jardim defende a possibilidade de o juiz condenar o réu mesmo após o pedido de absolvição pelo Ministério Público. Sua argumentação parte da crítica ao garantismo penal, de modo que se aproveita o trecho abaixo para dar início ao debate aqui proposto.

Tais doutrinadores sustentam ainda, dentre outras questões, que a possibilidade de o juiz condenar o réu, diante do opinamento pelo Ministério Público em prol da absolvição do réu, em suas alegações finais, macula diretamente o sistema acusatório e resulta também da formação autoritária de nossa sociedade (art. 385 do CPP). Aqui cabe mais uma crítica, embora não seja nossa intenção analisar todas as afirmações desta corrente garantista (aliás, o garantismo está mais parecendo uma "religião" do que outra coisa). Vamos a ela.

Na verdade, o mencionado art. 385 do CPP não poderia dispor de forma diferente e é resultante do princípio da indisponibilidade da ação penal pública (art. 42). O pedido de condenação não é retirado, sendo que, nas alegações finais, apenas se dá um "parecer" sobre a pretensão punitiva estatal, que está manifestada na denúncia e nela permanece. De qualquer forma, o legislador não tem saída: a) ou obrigaria o Ministério Público a insistir sempre e sempre na condenação do réu, o que seria um absurdo; b) ou obrigaria o juiz a absolver o réu e, neste caso, a decisão seria do próprio Ministério Público, que mandaria o juiz prolatar uma decisão meramente formal de absolvição, o que seria um despautério (JARDIM, 2014).

Em um primeiro momento, está correta a visão do doutrinador de que a epistemologia garantista não permite a atuação do juiz da forma prevista no art. 385 do CPP. Daí sua crítica ao modelo garantista, tipicamente acusatório. Oportuno, neste momento, passar brevemente pelos sistemas processuais. A doutrina costuma fazer referência a três modelos: acusatório, inquisitório e misto (por todos: PRADO, 2005, p. 99). Para Jacinto de Miranda Coutinho (1998), o que principalmente caracteriza o sistema inquisitório (ou inquisitivo) é a concentração de atos e de poder nas mãos do julgador, o qual detém a gestão da prova 
(COUTINHO, 1998, p. 166). Por sua vez, o sistema acusatório estaria caracterizado por garantir o poder de gestão da prova às partes, sobre o qual o juiz mantém-se inerte. "O processo, destarte, surge como uma disputa entre as partes que, em local público (inclusive praças), argumentavam perante o júri, o qual, enquanto sociedade, dizia a verdade, vere dictum (COUTINHO, 1998, p. 166).

O sistema misto teria surgido após as Revolução Francesa (PRADO, 2003, p. 3), reverberando nos demais países. O sistema misto, como exposto por Ferrajoli, seria "predominantemente inquisitivo na fase de instrução, predominantemente acusatório na fase de debate e dominado em ambas as fases pelo princípio da livre convicção do juiz-inquisidor" (FERRAJOLI, 2014, p. 134)

Parte do problema do sistema misto, criticado por Ferrajoli, seria a união de fórmulas epistemológicas distintas dentro do mesmo modelo. Distinguindo o que seria o modelo autoritário, de epistemologia inquisitiva (FERRAJOLI, 2014, p. 44), do modelo garantista, Ferrajoli coloca como central o problema da verdade:

A alternativa epistemológica entre os dois modelos - um estritamente juspositivista e o outro tendencialmente jusnaturalista - se manifesta, portanto, no distinto tipo de "verdade jurídica" por eles perseguida. A verdade a que aspira o modelo substancialista do direito penal é a chamada verdade substancial ou material, quer dizer, uma verdade absoluta e onicompreensiva em relação às pessoas investigadas, carente de limites e de confins legais, alcançá-

3 A respeito das diferenças, sustenta Ferrajoli: "Os principais problemas se referem às confissões e aos testemunhos, no mínimo porque tanto umas como outros comportam uma atividade inquiridora exercitada diretamente sobre pessoas. E nessas atividades que se exprimem os diversos estilos processuais: desde o estilo acusatório, em que é máximo o distanciamento do juiz, simples espectador do interrogatório desenvolvido pela acusação e pela defesa ao estilo misto, em que as partes são espectadoras e o interrogatório é conduzido pelo juiz, até o estilo inquisitório, no qual o juiz se identifica com a acusação e por isso interroga, indaga, recolhe, forma e valora as provas. Os diversos estilos assinalam a diversa relação suprailustrada entre meios e fins do processo: o primado do fim de uma verdade máxima no processo inquisitório, qualquer que seja o meio para atingi-la; o primado dos meios no processo acusatório, enquanto garantias de uma verdade mínima, mas o mais certa possível" (FERRAJOLI, 2014, p. 563). Grifo adicionado. 
vel por qualquer meio, para além das rígidas regras procedimentais. É evidente que esta pretendida "verdade substancial", ao ser perseguida fora de regras e controles e, sobretudo, de uma exata predeterminação empírica das hipóteses de indagação, degenera em juízo de valor, amplamente arbitrário de fato, assim como o cognitivismo ético sobre o qual se baseia o substancialismo penal resulta inevitavelmente solidário com uma concepção autoritária e irracionalista do processo penal (FERRAJOLI, 2014, p. 48).

Assim, na medida em que o art. 385 do CPP encontra lastro epistemológico no princípio da verdade real/substancial, mostra-se, portanto, sua matriz inquisitória, que é incompatível com o modelo acusatório orientado pela Constituição. A discussão específica sobre verdade real está nos itens seguintes.

Outra distinção significativa entre os sistemas acusatórios e inquisitivos está justamente no papel que o juiz pode assumir no processo penal. Nesse sentido, Ferrajoli é bastante assertivo ao explicar o axioma número 8 do sistema garantista (A8 do SG):

De todos os elementos constitutivos do modelo teórico acusatório, o mais importante, por ser estrutural e logicamente pressuposto de todos os outros, indubitavelmente é a separação entre juiz e acusação. Essa separação, exigida por nosso axioma A8 nullum iudicium sine accusatione, forma a primeira das garantias orgânicas estipuladas em nosso modelo teórico SG. Ela comporta não só a diferenciação entre os sujeitos que desenvolvem funções judicantes e os que desenvolvem funções de postulação e o conseqüente papel de espectadores passivos e desinteressados reservado aos primeiros em virtude da proibição ne procedat iudex ex officio, mas também, e sobretudo, o papel de parte - em posição de paridade com a defesa - consignado ao órgão da acusação e a conseqüente ausência de qualquer poder sobre a pessoa do imputado. Entendida nesse sentido, a garantia da separação representa, de um lado, uma condição essencial do distanciamento do juiz em relação às partes em causa, que, como veremos, é a primeira das garantias orgânicas que definem a figura do juiz, e, de outro, um pressuposto dos ônus da contestação e da prova atribuídos à acusação, que são as primeiras garantias procedimentais do juízo (FERRAJOLI, 2014, p. 522). 
Em outro trecho, Ferrajoli aponta que "O sistema 'sem acusação separada' S2, que configura o método inquisitivo, deriva, por sua vez, da subtração do axioma A8 sobre a imparcialidade do juiz e sobre sua separação da acusação" (2014, p. 96).

Nesse sentido, o sistema acusatório é marcado especialmente pela distinção clara das funções de acusar e de julgar. Isso não significa que o juiz não possa tomar a iniciativa em qualquer ato processual, como na tendência do modelo adversarial inglês e americano, em que as partes têm quase todo o domínio sobre os caminhos a serem tomados pelo processo. No modelo acusatório trazido por Ferrajoli, o juiz tem a função de garantir o contraditório e o devido processo legal, não significando que ele seja totalmente inerte.

Assim, o juiz deve atuar ativamente no sentido de garantir que as regras do jogo processual sejam iguais para as partes. Ao mesmo tempo, por sua vez, o sistema acusatório obriga o juiz a se afastar dos atos processuais típicos de parte, como, por exemplo, a produção de provas e a possibilidade de dar início à ação penal. Fatos esses que, necessariamente, maculam a imparcialidade do juízo.

Aliás, junto ao princípio da presunção de inocência, é do princípio da separação das funções de acusar e julgar que se infere que o ônus da prova incumbe exclusivamente a quem acusa, bem como o princípio dispositivo ne procedat iudex ex officio, do qual emana o dever de imparcialidade, desinteresse e inércia do juiz. Ainda a respeito da possibilidade de propositura da ação penal pelo juiz, é válida a seguinte citação acerca do referido princípio.

O que faz o Juiz quando procede ex officio? Constitui-se, simultaneamente, julgador e parte adversa do delinquente; dá a denúncia a si próprio, escolhe as testemunhas e inquire-as perguntando o que julga conveniente, e por fim avalia as provas que ele criou e pronuncia, então, como entende. E conclui: nada porém justifica o procedimento oficial qual a nossa lei estabelece, abuso dos antigos erros, abuso proscrito pelo virtuoso Malherbe: je cherche ici des juges et he ne trouve pas que des accusateurs (Pimenta Neves apud TOURINHO, 2012, p. 576) ${ }^{4}$.

\footnotetext{
4 "Je cherche ici des juges et he ne trouve pas que des accusateurs" pode ser tradu-
} zido por: Vim a procura dos juízes e encontrei nada além que os acusadores. 
É equivocada a noção de que o juiz deve manter-se distante das partes. Ao contrário, o juiz deve estar próximo das partes, ouvindo e analisando atentamente cada um de seus argumentos, inclusive buscando compreender a complexidade subjetiva, social e humana por traz de cada demanda.

A questão, portanto, não é de distância, mas de equidistância. A equidistância, ao mesmo tempo em que garante a imparcialidade do juiz frente às partes, é o que permite a necessária aproximação às demandas trazidas aos autos.

A equidistância, nesse sentido, orienta o juízo a não se distanciar das partes ao mesmo tempo em que lhe veda a possibilidade de aderir outros interesses que não estavam nas motivações que deram origem ao processo, posto que também vedado está o juiz a se aproximar de interesses estranhos aos que são levados ao processo.

O juiz jamais pode ter interesse em um processo em que lhe é vedado dar causa. O dever de assumir a condição de terzietà, por sua vez, torna o juiz vinculado ao interesse das partes, vedando-lhe a condição de protagonista no processo.

Pode-se defender o argumento de que, uma vez presente o pedido de condenação na inicial acusatória, o juiz não estaria agindo na posição de acusador, mantendo-se assim a higidez do modelo acusatório. No entanto, como se defenderá mais adiante, não se trata apenas de assumir a posição do acusador pelos atos típicos da acusação, como no pedido de condenar. Trata-se, também, de tomar a posição do acusador na narrativa processual acerca das provas produzidas.

Aliás, ao assumir posição autônoma e contrária às duas partes, o juízo verticaliza a relação processual e evidencia a lógica de um processo de um só sujeito.

É nesse sentido que as diferenças entre modelo teórico inquisitório e modelo teórico acusatório traçadas no parágrafo 39.2 podem ser vistas como expressões de duas opostas epistemologias do juízo: dictum de um só sujeito, ou contenda entre vários sujeitos; relação vertical inquisidor-inquirido, ou relação triangular entre duas partes e um terceiro supra partes; operação unilateral do juiz, ou actum trium personarum (FERRAJOLI, 2014, p. 557). 
Assim, a separação entre as funções dentro do processo (actum trium personarum) não se vale apenas sobre a capacidade postulatória, mas também na iniciativa sobre a narrativa processual. Da mesma forma que o juízo não pode oferecer a denúncia no lugar no Ministério Público, está vedado ao juízo entender haver crime onde o próprio Ministério Público entende não haver. Dessa forma, o julgador, quando condena o acusado contrariando o pedido de absolvição da própria instância acusadora, toma seu lugar na relação processual.

Por oportuno, sem deixar de entrar na questão da condição processual do MP no processo, mas também sem transformar esse tema no elemento central deste artigo, mostra-se conveniente a transcrição das conclusões de Gustavo Badaró, que mostra a necessária relação do modelo constitucional acusatório com a consideração do MP como efetiva parte no processo:

Contudo, a concepção do Ministério Público como parte imparcial é incompatível com o processo penal acusatório, que exige um processo no qual haja uma dualidade de parte, em igualdade de condições, e com interesses distintos. Definido o sistema, os sujeitos que nele atuam devem ter a sua função determinada coerentemente com os ditames do modelo processual escolhido. Em um processo penal verdadeiramente acusatório, é necessário rever a posição do Ministério Público como parte imparcial.

(...)

Conceber o Ministério Público com parte imparcial significa inviabilizar a dialética de partes ou, ao menos, tornar a composição entre tese e antítese algo artificial ou meramente formal. No processo acusatório, em que se acentual a relação dialética entre as partes, o Ministério Público deve ser uma parte verdadeira, isto é, uma parte parcial (BADARÓ, 2016, p. 289 e 290)

\section{Os LIMITES DO PEDIDO DE CONDENAÇÃO NA DENÚNCIA E A IMPORTÂNCIA DAS ALEGAÇÕES FINAIS}

Relevante mencionar o equívoco cometido por Afrânio Jardim ao evocar o princípio da indisponibilidade da ação penal pública presente no art. 42 do CPP. 
A questão é simples. O referido princípio meramente retira do Ministério Público a faculdade de dispor sobre a ação penal. Ou seja, o MP não tem poder discricionário para atestar a conveniência e oportunidade da ação penal pública, devendo acionar o Judiciário todas as vezes que é confrontado com uma conduta que entende ser criminosa, tampouco tem o poder de retirar a ação proposta ou arquivar o processo. No entanto, não está obrigado o membro do Ministério Público a denunciar quando entende não haver crime, muito menos a requerer a condenação, ou nela insistir, quando convencido da inocência do acusado.

Nesse ponto, é importante falar da denúncia. Qual sua real função no processo? Trata-se de uma provocação judicial que objetiva o juízo de admissibilidade da acusação. A verdade é que a denúncia tem a pretensão de que seja oportunizada à acusação provar o narrado. O que se pede, verdadeiramente, é a procedência da ação para que seja oportunizada a produção de provas.

Como pedir que uma pessoa seja condenada sem que haja provas produzidas contra ela? Assim, a denúncia não deveria ser tratada para além de um pedido de avaliação da pretensão acusatória. Trata-se de uma provocação judicial que objetiva o juízo de admissibilidade da acusação.

Não há dispositivo legal que vincula o pedido de condenação logo na inicial. O próprio artigo 41 do CPP não o elenca como condição mínima da denúncia. Faz sentido. O pedido de condenação na exordial acusatória penal é mero sintoma da tradição civilista no processo penal.

Assim, eventual pedido de condenação ventilado na denúncia somente se completa se, após a produção das provas, o Ministério Público o mantém. Do contrário, seria aceitar um caminho sem volta, sem a oportunidade de reconhecimento do erro. Recebida a denúncia, as partes não podem rebaixar-se à condição de figurantes processuais, meros coadjuvantes em um processo efetivamente inquisitorial.

Se o juiz não pode condenar logo após a fase postulatória, sem provas, eventual pedido de condenação na denúncia há de ser considerado precário, necessariamente dependente de um momento posterior à produção das provas, em que o pedido de condenação esteja efetivamente lastreado. 
No mesmo sentido, é sabido que o Procurador Geral, ao designar novo promotor após aplicação do art. 28, não entende necessariamente pela condenação. A designação reflete tão somente o entendimento de que é necessária a instrução, de que o arquivamento não é suficiente para a emissão de qualquer conclusão.

Ora, se o MP tivesse acesso às provas antes da propositura da ação, sequer haveria denúncia. Sequer estaria oportunizado ao juiz a dar seu entendimento sobre a contenda. Entendendo o Ministério Público pela absolvição, seja por insuficiência de provas ou por atipicidade, por exemplo, atesta perante o juízo que errou na propositura da ação penal, que não deveria tê-la feito contra uma pessoa inocente.

É nesse sentido que emerge a importância das alegações finais. Muito mais do que mero parecer, as alegações finais são a complementação necessária do pedido condenatório, é a confirmação definitiva da pretensão acusatória. É em alegações finais, apresentando narrativa com provas produzidas em contraditório, que está completo o requerimento para condenar. Somente neste momento que ele pode efetivamente ser atendido. "Acontece que o oferecimento da denúncia não esgota por si a acusação, posto que ela deve perdurar até o momento de uma eventual condenação. Quando o MP pede a absolvição, materialmente está retirando a acusação e, portanto, é impossível a condenação do réu" (FREIRE JÚNIOR, 2005, p. 19).

No sistema acusatório, consoante com a Constituição Federal, não pode o juiz levar adiante a pretensão punitiva quando a pretensão acusatória não foi exercida de forma exitosa. Entender o contrário levaria o juiz à condição de interessado no processo, elevando sua posição perante a tríade processual.

A força normativa da titularidade da ação penal pelo MP é condição sine qua non da nossa democracia. Sem a real titularidade, não há processo acusatório, mas inquisitório, em que basta um juiz, que concentra os atos do começo ao fim, sem as partes, para promoção da instrução e da condenação.

Se o próprio órgão acusador, que detém o ônus da prova, sustenta que não conseguiu provar o alegado, deixa de existir qualquer narrativa capaz de lastrear uma sentença condenatória. Sem a devida invocação, não há a motivação necessária para a condenação. 
Parte da doutrina nacional vem defendendo a impossibilidade de condenação após o pedido de absolvição do Ministério Público. Alexandre Morais da Rosa sustenta que o art. 385 do CPP não é compatível com o processo entre jogadores e constitucional, defendendo que a decisão dos julgadores deve estar vinculada aos limites do pedido em alegações finais, "sob pena de trazer para si o objeto do processo" (MORAIS DA ROSA, 2016, p. 481).

No mesmo sentido, Paulo Queiroz sustenta que “ao juiz não é dado iniciar o processo de ofício (ne procedat iudex ex officio), tampouco condenar o réu quando o Ministério Público, titular da ação penal, com boas ou más razões, propuser a absolvição" (QUEIROZ, 2016). Defende que, havendo discordância por parte do juízo da tese final formulada pelo Ministério Público, deve-se aplicar o disposto, em analogia, no art. 28 do CPP, remetendo os autos ao chefe do Ministério Público para decisão final do tema.

Para Aury Lopes Jr., o requerimento de absolvição do Ministério Pública representa a retirada da pretensão acusatória, de modo que eventual condenação violaria o princípio do ne procedat iudex ex officio e o da correlação, vez que inviabiliza uma decisão construída em contraditório (LOPES JR., 2014) ${ }^{5}$.

Na sequência, buscando trazer alguma novidade ao tema, fala-se da relação entre o art. 385 do CPP com o princípio da verdade real, sendo este, em verdade, seu fundamento epistemológico.

\section{A VERDADE REAL COMO PRESSUPOSTO EPISTEMOLÓGICO PARA A AUTONOMIA NARRATIVA DO JUIZ}

$\mathrm{O}$ argumento que subjaz à possibilidade de um juiz condenar um réu mesmo havendo manifestação expressa do MP para absolver não está nos tecnicismos processuais. O cerne da questão é o seguinte: o processo apresenta uma narrativa autônoma, para além das partes ativas no processo?

5 No mesmo sentido, além dos autores já citados, vale a lembrança do posicionamento de Vladimir Aras (2013) e Elmir Duclerc (2008, p. 128), para os quais o art. 385 também é incompatível com a Constituição e com o modelo acusatório. 
Somente a crença (crença porque depende de fé) da falecida e falaciosa ideia de verdade real (substancial ou material, que é a verdade real travestida de falso garantismo) permitiria o "sim" como resposta para a pergunta acima. "A rigor, a verdade real é um mito. A verdade, como correspondência entre um dado e a realidade, é uma só. (...) Para falar em verdade real, é necessário supor a existência de outra verdade, então, irreal e, portanto, não verdadeira” (CASARA, 2013, p. 177).

O Direito talvez seja a única área do conhecimento que ainda crê na ideia de verdade real, enterrada inclusive nas áreas das ciências exatas, que já reconhecem que o sujeito da relação científica é ativo, tendo influência subjetiva, na formação da conclusão de uma observação. Nas ciências exatas, em poucas palavras, não mais se crê no alcance da Verdade (com V maiúsculo mesmo), mas num grau de certeza e comprovação que permite a reprodução de comportamentos sobre situações iguais ou similares, inclusive reconhecendo a subjetividade do cientista na determinação das características do objeto estudado.

A propósito, é válida a discussão acerca do princípio da incerteza, travada já na década de 1920 na comunidade científica. Em síntese: "O elétron, o próton ou o nêutron reais não são nem uma coisa nem outra, mas uma composição de ambas. Certa característica só aparece quando um experimentalista intervém e seleciona qual aspecto medir" (BALKER, 2015, p. 69).

Os mais cautelosos já não falam mais em verdade absoluta, e suavizam o termo "verdade real" no sentido de que o princípio indica a ideia de "aproximação do que realmente aconteceu". O erro permanece. Essa assertiva pressupõe um sujeito que, ao mesmo tempo que reconhece a impossibilidade de se dizer sobre a verdade absoluta, não deixa de considerá-la como existente, ainda que inalcançável, tal como Platão. Comum, ainda, reconhecer que verdade real admite a ideia de verdade relativa, mais uma vez caindo no mito da "aproximação" e sem deixar, no fundo, de pressupor epistemologicamente numa verdade que existe para além dos sujeitos.

No entanto, é preciso dizer de forma bastante peremptória. $\mathrm{O}$ princípio da verdade real, sobrevivendo às custas de desconhecimento científico e filosófico, bem como a partir de eufemismos astuciosos, 
deve ser finalmente enterrado na história do direito processual penal, uma vez que representa em si o mais altivo princípio inquisitivo.

O problema da verdade real apresenta duas problemáticas centrais, uma de ordem filosófica e uma de ordem político-jurídica.

A questão filosófica se dá no sentido de que já não se admite mais a ideia de uma verdade inalcançável, exterior ao mundo dos sujeitos e das percepções. O novo paradigma, de ordem epistemológica e hermenêutica, considera que não é possível uma apreensão objetiva da realidade, revelando que há sempre uma determinação de ordem prescritiva acerca do fato na atividade interpretativa. O que se diz então, em poucas palavras, é que a verdade não passa de uma construção narrativa dos atores em jogo, a ser dirigida a seus interlocutores para que se interprete e se dê sentido aos fatos narrados, mas sempre acompanhado de um aspecto subjetivo.

Citando Gadamer, Felipe Kirchner explica como o processo interpretativo é também um processo construtivo, e não de acesso, como pressupõe a verdade real:

No viés gadameriano o objeto não tem um significado independente do evento que é compreendê-lo, nem a compreensão é independente da vida. As normas e os eventos fáticos que são objetos do processo criminal não existem como entidades verdadeiramente normativas antes do momento da interpretação, que passa a ser um ato de decisão que constitui e constrói as respectivas significações. Em síntese: o sujeito cognoscente sempre cria enquanto interpreta (KIRCHNER, 2009, p. 122).

A prova no processo penal tem por objetivo a construção de uma narrativa, não a construção de uma verdade: "A verdade não 'escolhe' a forma de sua manifestação e nem 'imprime força de convencimento' às palavras. Tal coisa somente poderia ocorrer no terreno da ficção, da magia, do mito, onde não há limites, ou da crença religiosa, onde o limite é Deus - que não tem limites" (VARGAS, 2011, p. 146).

Aliás, toda memória, seja ela pessoal ou documental, é a reconstrução de um determinado fato histórico, nunca ele em si mesmo. Uma vez alcançando o passado apenas por "meios”, só se pode falar em revisita, em percepção. Até mesmo se fosse possível a reprodução 
exata de um fato por todos os ângulos possíveis, os ânimos dos agentes seriam já outros.

A realidade aparece às pessoas como uma infinitude de sinais cognitivos, o que é "filtrado" pela percepção. Ela é realizada pelos sentidos limitados dos seres humanos, não encontram por si só um sentido para o que o corpo recebe, necessitando para isso o juízo, a mente, que vem a interpretar, explicar, numa atividade lógica de conclusão, aquilo que foi percebido (MERLEAU-PONTY, 2006, p. 62). "A percepção torna-se uma 'interpretação' dos signos que a sensibilidade fornece conforme os estímulos corporais, uma 'hipótese' que o espírito forma para 'explicar-se suas impressões'” (MERLEAU-PONTY, 2006, p. 61-62).

No mesmo sentido, Oliver Sacks entende que toda percepção é também um ato de vontade: "os processos perceptivos-cognitivos, enquanto fisiológicos, também são pessoais - não se trata de um mundo que a pessoa percebe e constrói, mas de seu próprio mundo -, e levam a, estão ligados a, um eu perceptivo, com uma vontade, uma orientação e um estilo próprios” (SACKS, 2006, 139). Somando a essa ideia, Merleau-Ponty vai dizer que não há reflexão que não seja também uma transformação do próprio eu: "A reflexão só é verdadeiramente reflexão se não se arrebata para fora de si mesma, se se conhece como reflexão-sobre-um-irrefletido e, por conseguinte, como uma mudança de estrutura de nossa existência" (MERLEAU-PONTY, 2006, p. 97).

Falar do passado é também falar da memória. A respeito, François Ost (2005), disserta sobre os quatro paradoxos da memória.

Primeiro paradoxo: a memória é social e não individual. (...) Acontece que nossas lembranças, até as mais pessoais e mais íntimas, só conseguem se exprimir em termos tomados de empréstimo à tradição; eles só fazem sentido, por outro lado, sendo tomados por uma comunidade afetiva e social que não demora, aliás, em retrabalhá-los (OST, 2005, p. 57).

Segundo paradoxo: longe de proceder do passado, a memória opera a partir do presente. (...) assim, então, não somente a recordação é social, mas ainda resulta, em ampla medida, de uma reelaboração com a ajuda dos dados tomados de empréstimo ao presente, tanto quanto ao passado próximo, ou seja, às reconstruções intermediárias que já interpretaram consideravelmente, por 
sedimentações sucessivas, o material originário. Logo, nada de memória sem (re)interpretação coletiva (Idem, p. 57).

O terceiro paradoxo da memória situa-se no prolongamento direto do precedente: se a memória opera a partir do presente e não do passado, é que ela é uma disposição ativa, voluntária mesmo, antes que uma faculdade passiva e espontânea (Idem, p. 58).

Entretanto, falta-nos ainda indicar um quarto - e não dos menores paradoxos da memória - ligado desta vez à usa relação com o esquecimento: longe de se opor ao esquecimento, a memória o pressupõe. Melhor dizendo, qualquer organização da memória é igualmente organização de esquecimento. Nada de memorização sem triagem seletiva, nada de comemoração sem invenção retrospectiva. Logo, a memória pode tanto ser fundadora e instituinte como acabamos de sublinhar, como pode mostrar-se manipuladora e mistificadora: estas duas funções são necessariamente solidárias (Idem, p. 60).

Em resumo, a memória é: social, e dependente da tradição e das construções afetivas; é avaliada a partir do presente, que dele toma empréstimo de elementos de elaboração; é um ato de vontade; e, talvez o mais importante, é esquecimento.

A memória pressupõe o esquecimento. Ser esquecimento significa dizer que é justamente aquilo que buscamos esquecer que constitui a memória. Essa ideia é de suma importância para o que se vem tentando defender: a necessidade da presença dos meios e de fontes de prova ao processo, para avaliação, em conjunto, do fato a ser lembrado. Ora, quando uma das partes já escolhe os elementos de convicção que serão descartados (esquecidos) ou não, já está sendo feito aí a construção ativa da narrativa a ser avaliada pelo juízo ${ }^{6}$.

6 Dessa maneira, é possível concluir, pelas palavras de Ferrajoli, que "nenhuma prova, indício ou conjunto de provas e de indícios, garante inimpugnavelmente a verdade da conclusão fática. Não existe, a rigor, provas suficientes" (FERRAJOLI, 2002, p. 109). Porém, a impossibilidade epistemológica de se dizer a verdade sobre determinado fato não exclui a possibilidade de decisão, desde que esta seja compreendida enquanto uma "justificação relativa”. Isso significa que a decisão não precisa pressupor que se alcançou a verdade dos fatos, mas tão somente que a narrativa construída a partir das provas foi 
Superado o problema da verdade em seu sentido filosófico, importante destacar a outra dimensão desse problema, o de ordem político-jurídico.

A questão político-jurídica se dá no sentido de que o princípio da verdade real apresenta relação direta com o sistema inquisitorial, no qual o juiz concentra os atos processuais, cumprindo as funções de acusar, gerir e produzir as provas e julgar. "No sistema inquisitório, nasce a (inalcançável e mitológica) verdade real, em que o imputado nada mais é do que um mero objeto de investigação, 'detentor da verdade de um crime', e, portanto, submetido a um inquisidor que está autorizado a extraí-la a qualquer custo" (LOPES JR., 2016, p. 169).

A associação se dá justamente porque é a ideia de verdade real que permite ao juiz atuar ativamente no processo, no mito de que a verdade dos fatos não pode ser alterada ou sofrer influência dos atos e percepções do juiz. Nesse sentido, o princípio da verdade real está relacionado a um regime político-jurídico autoritário (FERRAJOLI, 2014, p. 44-48) que mitiga o contraditório.

A negação de uma verdade real está intimamente ligada à também negação do modelo inquisitório, onde ainda se fala em obtenção da verdade, fins justificando meios, confissão forçada, violência física etc. A sedimentação do modelo acusatório, de uma lógica garantista em que se busca garantir os direitos fundamentais da CF/88 enquanto carta dos princípios democráticos, depende dessa negação à verdade real e de uma busca constante desses direitos.

A própria questão da prova ilícita iniciou-se justamente para impor limites ao princípio da verdade real. A ideia de verdade real, como conclusão lógica, tem em si a tendência natural de fomentar procedimentos e práticas extraoficiais e extra-autos.

"A busca da verdade real como finalidade da praxis judicial fincou-se como um dos principais pilares dogmáticos que sustentavam o processo inquisitório" (PINTO, 2010, p. 198). Até hoje, muitos operadores do direito trabalham na ideia de verdade real como o foi no sis-

suficiente para que uma decisão fosse tomada, o que também não indica o caminho ao decisionismo, mas a uma sentença devidamente juridicamente fundamentada. 
tema inquisitório e, com base no princípio, buscam a relativização das garantias processuais e a admissão das provas ilícitas ${ }^{7}$.

A questão do substancialismo penal, tão bem apresentada por Ferrajoli (2014, p. 44), trata exatamente da condição secundária e instrumental do processo frente ao objeto material. O substancialismo penal pressupõe que as formas e formalidades não têm função própria ou que são neutras politicamente, na toada do absurdo art. 566 do CPP.

A respeito da diferença entre as sensibilidades jurídicas dos modelos estadunidense e brasileiro, Kant de Lima traça um perfil comparativo de como é o trabalho jurisdicional sobre a construção da verdade no processo penal. Aponta como que, no Brasil, o acusado pouco tem a possibilidade de trabalhar a questão da narrativa processual, cabendo-lhe quase nenhum espaço na constituição da verdade no processo. A verdade é dada de maneira vertical, a partir de uma autoridade que tem a faculdade de acolher ou não as teses levantadas pelas partes.

Explica Kant de Lima:

Aqui [no Brasil], dada a desigualdade legal e explícita entre os interlocutores, é o argumento de autoridade que prevalece na administração dos conflitos e não a autoridade do argumento, que convence as partes envolvidas. Isto se reflete também nos debates jurídicos e políticos, que levam a que decisões coletivas se constituam na soma de decisões singulares, mesmo quando elas são proferidas em espaços coletivos, como os tribunais de segunda e terceira instâncias. Os saberes particulares não precisam do consenso, e nem o desejam, para concordar, porque o consenso não legitima, pelo contrário, "contamina" suas formas

7 A admissão das provas ilícitas, além do substancialismo penal denunciado por Ferrajoli, que coloca as garantias processuais como fator de menor relevância no litígio penal, tem como pano de fundo a ideia de verdade real. $\mathrm{O}$ princípio da proporcionalidade, mal aplicado, verdadeira carta trunfo de um punitivismo a-histórico, lembra o velho manual dos inquisidores: "Quando se pode dizer que alguém foi suficientemente torturado? Quando parecer aos juízes e especialistas que o réu passou, sem confessar, por torturas de uma gravidade comparável à gravidade dos indícios” (BUENO, 2012, p. 59). Quando as provas ilícitas poderão ser aceitas no processo? "Quando a ilicitude for inferior à gravidade do delito", respondem os favoráveis saudosos do decisionismo medieval, que sempre remete ao bom senso dos "especialistas" e não à Carta Magna que veda, sem exceções, as provas ilícitas nos processos. 
particularizadas de acessar o conhecimento jurídico (KANT DE LIMA, 2009, p. 43-44).

Na tradição jurídica dos EUA tem-se que as partes possuem um papel muito mais ativo na construção da verdade no processo, podendo inclusive ser totalmente construída pelas partes e ser apenas homologada pelo juiz. Nesse cenário, em tese, as garantias processuais penais encontram relevância primordial, no sentido de que somente com sua presença é possível presumir que há o devido contraditório. Ou seja, sem as garantias processuais, não há de se falar em disputa justa entre as partes, sendo fundamental para o devido processo legal.

Por sua vez, na tradição jurídica brasileira, por ainda estar presente a ideia de verdade real, tem-se que os aspectos materiais que envolvem o processo acabam encontrando mais relevância em detrimento das garantias processuais. A verdade real e sua matriz inquisitória explicam a tendência de o judiciário brasileiro ter mais flexibilidade em validar provas de duvidosa licitude do que nos EUA.

Assim, o princípio da verdade real revela-se como recurso discursivo que autoriza o juiz a buscar elementos, inclusive de ofício, extra-autos, reduzindo a importância das narrativas levantadas no processo pelas partes, bem como das garantias processuais como pressuposto do contraditório e do devido processo legal, além de elevar o juiz à condição de protagonista no processo.

É nesse sentido que a condenação do réu quando as partes entendem pela absolvição tem relação com a verdade real.

Permitir ao juiz a invocação de uma narrativa autônoma no processo, não levantada pelas partes, é deslocá-lo da condição de imparcial, uma vez que o retira de sua inércia devida e o coloca como parte ativa a atuante no processo. Não é só pelos atos que o juiz manifesta sua imparcialidade, mas também na narrativa usada na decisão ${ }^{8}$. A esse res-

8 Esse quadro se acentua quando ao julgador é facultado a produção de provas, trazendo o ônus da prova para si e reduzindo a tutela exclusiva da ação penal do MP a mero apêndice do poder jurisdicional. A concentração de atos processuais é o próprio cerne do modelo inquisitorial, que aniquila a imparcialidade do julgador e reduz a defesa ao plano burocrático e protocolar, mera forma, mero discurso de encobrimento de sua parcialidade. 
peito, válida é a lembrança ao art. 10 do Novo Código de Processo Civil: "O juiz não pode decidir, em grau algum de jurisdição, com base em fundamento a respeito do qual não se tenha dado às partes oportunidade de se manifestar, ainda que se trate de matéria sobre a qual deva decidir de ofício". O dispositivo evidencia haver lesão ao contraditório quando o juiz se baseia em fundamento não versado ou de conhecimento das partes. Evita-se, portanto, a surpresa na decisão9.

O processo penal democrático não pode se destinar à produção da verdade real, mas à construção de uma narrativa que visa a convencer o julgador. Se o próprio órgão acusador, aquele que tem o dever de provar o que narrou na inicial, sustenta que não conseguiu provar o alegado, deixa de existir qualquer narrativa capaz de lastrear uma sentença condenatória.

Compreendendo-se a decisão como construção narrativa, a verdade permanecerá sempre irrealizada. Resta apenas seu caráter analógico:

E se a verdade é reconstruída narrativamente sob o signo do Análogo, isso significa que a verdade é algo essencialmente contingente: ao final restará apenas representância, o que só pode significar que a ênfase deve residir nas regras do jogo e na contenção ritualizada do poder punitivo através do devido processo legal (KHALED JUNIOR, 2016, p. 521).

Nessa compreensão é que se ressalta a importância das alegações finais no processo. É possível um processo sem alegações finais? Para quê elas servem? É justamente o momento no processo que se monta a narrativa, com os elementos de prova produzidos (ou não), que permitirão ao juiz basear sua condenação ou absolvição. Sem essa narrativa, o juiz teria de recorrer à verdade real, existente no plano das ideias, numa ontologia platônica que, na realidade, é tão somente a manifestação da parcialidade do julgador.

9 A propósito: “O principal fundamento da comparticipação é o contraditório como garantia de influência e não surpresa. [...] Nesse sentido, o princípio do contraditório receberia uma nova significação, passando a ser entendido como direito de participação na construção do provimento, sob a forma de uma garantia processual de influência e não surpresa para a formação das decisões" (THEODORO JR., 2015, p. 63). 
Na crença da verdade real, a defesa se vê em uma luta extraprocessual, sem espaço efetivo para se manifestar. "A atribuição de uma função da 'busca da verdade real' ao juiz somente maximiza o potencial de danos do sistema, pois a verdade produzida a partir dessa perspectiva sequer analógica será; será a expressão de uma violência, uma fantasmagoria que pouca relação guardará com a realidade" (KHALED JUNIOR, 2016, p. 514).

Aliás, aceitar a ideia de que o juiz pode condenar mesmo com pedido de absolvição do MP nos autoriza a pressupor que o julgador já estaria com a convicção formada antes mesmo do fim do processo, o que, por si só, já seria elemento suficiente para questionar a imparcialidade do julgador.

Em síntese, não se trata de dizer que passa ao MP a competência para condenar ou absolver, mas de dizer que o juízo é dependente materialmente das narrativas formuladas pelas partes, não estando ele autorizado a entrar como terceira parte no processo e criar uma narrativa própria e autônoma, sustentada, no fim das contas, numa fantasia identificada como verdade real.

Equivoca-se quem compreende o que foi dito acima no sentido de que o juiz teria de aceitar em sua completude uma das narrativas apresentadas no processo, estando impossibilitado ao juiz apresentar algo além do que foi dado pelas partes.

A inteligência do art. 212 e seu parágrafo único do CPP nos permite concluir que o juiz, no modelo acusatório, mantém sua autonomia e sua subjetividade presente no processo, mas sempre dependente das partes e decorrente delas.

A imparcialidade do juízo não é só em relação às partes, na tendência de se aproximar de uma parte ou de outra, mas também em relação a si mesmo, devendo o juiz se afastar (ou ao menos ponderar) suas ideologias próprias e impressões pessoais e subjetivas.

Ou seja, a vinculação do juiz ao que foi levado pelas partes no processo é uma forma também de garantir que o juiz não apresente no processo sua posição individual ou suas impressões pessoais que pouco ou nada tem a ver com sua condição de juiz. Em síntese, não é porque o juiz está vinculado às narrativas trazidas ao processo que o juiz deva se valer de uma relação de tudo ou nada. 
Em mais um de seus brilhantes momentos, Carnelutti disserta sobre a necessidade e razão de ser da parcialidade das partes. As partes devem ser parciais no processo justamente para que o juiz tenha acesso aos dois extremos e poder concluir e sintetizar da melhor forma possível, tendo passado por toda uma amplitude de cenários no processo. "Acusador e defensor são, em última análise, dois raciocinadores: constroem e expõem as razões. O ministério deles é raciocinar" (CARNELUTTI, 2015, p. 41). Resta aí a essência do contraditório.

A possibilidade de um juiz condenar havendo convergência das narrativas processuais no sentido da absolvição ofende não somente a imparcialidade do juiz, mas também o contraditório.

Por que razões as alegações finais da defesa são posteriores a do acusador? Para permitir à defesa se defender da narrativa processual que contra ele foi levantada. Para permitir à defesa contraditar a interpretação acerca das provas que podem condená-lo.

No entanto, como poderá a defesa contraditar a narrativa acerca das provas de uma sentença penal condenatória? Contra juiz, não há contraditório.

Estando a narrativa acusatória, em sede de alegações finais, em concordância com a defesa no sentido de absolvição, a sentença condenatória, por apresentar narrativa inédita no processo, impossibilita a defesa de contraditá-la. Não há contraditório e, muito menos, ampla defesa.

A sentença condenatória diante de um pedido de absolvição do acusador é sempre uma surpresa, um elemento novo no processo, do qual a resposta defensiva é inviabilizada. Como sustenta Geraldo Prado:

Como o contraditório é imperativo para a validade da sentença que o juiz venha a proferir, ou, dito de outra maneira, como o juiz não pode fundamentar sua decisão condenatória em provas ou argumentos que não tenham sido objeto de contraditório, é nula a sentença condenatória proferida quando a acusação opina pela absolvição (PRADO, 2005, p. 189).

(...)

Assim, quando em alegações finais o Ministério Público opina pela absolvição do acusado o que ocorre em concreto, no processo, é que o acusador subtrai do debate contraditório a matéria 
referente à análise das provas que foram produzidas na etapa anterior e que possam ser consideradas desfavoráveis ao réu. Como poderá a defesa reagir a argumentos que não lhe foram apresentados (PRADO, 2005, p. 118).

Aliás, "vencido" seu algoz na disputa processual, convencido pela parte contrária acerca da verdade produzida nos autos, não pode o juiz vir a substituí-la.

Tanto a defesa quanto a acusação são levadas a uma posição de hipossuficiência na relação processual, cujo litígio não se dá mais entre-partes, mas contra o juízo, não em direção a ele, como exige o sistema acusatório.

\section{Considerações Finais}

O sistema acusatório, tal como proposto por Ferrajoli, pressupõe a distinção clara e efetiva entre as funções de julgar e de acusar. Essa distinção, no entanto, não pode estar restrita a atos processuais. Ainda que certos atos sejam privativos das partes ou do juiz, a separação efetiva deve pressupor também as limitações que o juiz deve ter ao assumir a posição de acusador quando este abandona seu papel ao longo do processo. Assim, o princípio do actum trium personarum não pode ser considerado apenas para questões formais, mas também sobre a iniciativa narrativa processual. Da mesma forma que o juízo não pode oferecer a denúncia no lugar no Ministério Público, está vedado ao juízo entender haver crime onde o próprio acusador defende não haver.

Dessa forma, o julgador, quando condena o acusado contrariando o pedido de absolvição da própria instância acusadora, toma seu lugar na relação processual, ofendendo sua condição de imparcial no processo.

Fato é que o pedido de condenação na denúncia, se presente estiver, deve ser compreendido como precário, a ser confirmado em alegações finais, momento de confirmação da pretensão acusatória.

Com efeito, impróprio haver pedido de condenação de um sujeito sem que haja provas produzidas contra ele. A denúncia, em verdade, é uma provocação judicial que objetiva o juízo de admissibilidade da acusação. 
A condenação posterior à requisição de absolvição do MP não só reduz o MP a mero menino da porteira, como transforma as alegações finais em momento inútil no processo, vez que o juiz, ao condenar, mostra que já estava com a convicção formada antes mesmo da principal e derradeira manifestação das partes.

Se o próprio acusador, que tem o dever de provar o que alegou na inicial, sustenta que não conseguiu provar o alegado ou de que está provado não haver crime, deixa de existir qualquer narrativa capaz de lastrear uma sentença condenatória. A certeza do acusador em absolver impõe, no mínimo, a dúvida ao magistrado, obrigando-o a invocar o in dubio pro reo.

Afinal, onde o juiz busca a narrativa para condenar quando ambas as partes entendem pela absolvição? Por óbvio, na falta de narrativa capaz de autorizar eventual condenação, o juiz passa a criá-la, de forma inédita, não provocada, e autônoma, no processo.

A possibilidade de o juiz desenvolver narrativa autônoma, contrariando as partes, está, no fundo, baseada na ideia de verdade real, princípio basilar do modelo inquisitivo, que confunde as funções de acusar com a de julgar.

Demonstrou-se que a verdade real apresenta dois problemas centrais, um de ordem epistemológica e outro de ordem político-jurídica.

O de ordem epistemológica se dá no sentido de que a verdade inexiste para além das partes, que é quem dá sentido e significado - a partir dos significantes disponíveis na linguagem e limitada ao meio em que elas estão (o processo) - aos fatos.

Não há descrição sem prescrição. Assim, quando o juiz apresenta narrativa processual inédita e autônoma no processo, ele toma a função e a condição de parte, contrariando o princípio acusatório e o da imparcialidade. O problema de ordem político-jurídico se dá no sentido de que a verdade real força o julgador a buscar elementos extra-autos e a validar atos e provas ilícitas em prol do âmbito material, evidenciando verdadeiro substancialismo penal, que reduz as formalidades processuais a mero instrumento punitivo, impedindo de fazer valer as garantias processuais.

Nesse sentido, a verdade real se revela como recurso discursivo que permite ao juiz ignorar e precarizar a função das partes no processo, fazendo se valer como elemento central e principal no processo. 
Afinal de contas, contra juiz não há contraditório. Assumindo a narrativa acusatória, o juiz, por apresentá-la somente na sentença, viola o contraditório e a ampla defesa, uma vez que inviabiliza a defesa de contraditar a interpretação das provas que permitiria eventual condenação.

Nesse quadro, tem-se que o art. 385, ao apresentar, como pressuposto epistemológico, o princípio da verdade real, se insere no contexto de um processo penal que ainda não é compatível com o sistema acusatório. Ao contrário, o art. 385 mantém viva a matriz inquisitória e autoritária do processo penal brasileiro, que pouco consegue ser adequado à luz da Constituição Federal.

\section{REFERÊNCIAS BIBLIOGRÁFICAS}

ARAS, Vladimir. O art. 385 do CPP e o juiz inquisidor. Disponível em <https:// vladimiraras.blog/2013/05/25/o-art-385-do-cpp-e-o-juiz-inquisidor/>. Acesso em: 13 mar. 2017.

BUENO, Carlos Manoel. Código de Hamurabi, Manual dos Inquisidores, Lei das XII tábuas, Lei de Talião. $2^{\text {a }}$ ed. São Paulo: Leme, 2015.

BADARÓ, Gustavo Henrique. Processo Penal. 4ª ed. São Paulo: RT, 2016.

BALKER, Joanne. 50 ideias de física quântica que você precisa conhecer. $1^{\mathrm{a}}$ ed. São Paulo: Planeta, 2015.

CASARA, Rubens R. R. Mitologia processual penal. São Paulo: Saraiva, 2015.

CARNELUTTI, Francesco. As misérias do processo penal. $3^{\mathrm{a}}$ ed. Leme/SP: Edijur, 2015.

DUCLERC, Elmir. Direito processual penal. Rio de Janeiro: Lumen juris, 2008.

KANT DE LIMA, Roberto. Sensibilidades jurídicas, saber e poder: bases culturais de alguns aspectos do direito brasileiro em uma perspectiva comparada. Anuário Antropológico, v. 2009, nº 2, p. 25-51, 2010.

KHALED JUNIOR, Salah Hassan. A busca pela verdade no processo penal: para além da ambição inquisitorial. $2^{\mathrm{a}}$ ed. Belo Horizonte, MG: Letramento: Casa do Direito, 2016.

FERRAJOLI, Luigi. Direito e Razão: Teoria do garantismo penal. $4^{\mathrm{a}}$ ed. São Paulo: RT. 2014. 
FREIRE JÚNIOR, Américo Bedê. Da Impossibilidade do Juiz Condenar Quando Há o Pedido de Absolvição Formulado pelo Ministério Público. Boletim do IBCCRIM, $\mathrm{n}^{\circ} 152$ - julho 2005.

JARDIM, Afrânio Silva. Garantismo no processo penal merece breve (e parcial) reflexão. Conjur. 2014. Disponível em: <http://www.conjur.com.br/2014jul-08/afranio-jardim-garantismo-processo-penal-merece-reflexao>. Acesso em: 01 abril. 2017.

KIRCHNER, Felipe. A Utopia da Verdade Real: compreensão e realidade no horizonte da hermenêutica filosófica. Revista Brasileira de Ciências Criminais, v. 80, p. 119-149, 2009.

LOPES JÚNIOR, Aury. Por que o Juiz não pode condenar quando o Ministério Público pedir a absolvição? 2014. Disponível em <http://www.conjur.com.br/2014dez-05/limite-penal-juiz-nao-condenar-quando-mp-pedir-absolvicao>. Acesso em: 13 mar. 2017.

LOPES JR., Aury. Fundamentos do processo penal: introdução crítica. $2^{\mathrm{a}}$ ed. - São Paulo: Saraiva, 2016.

MERLEAU-PONTY, Maurice. Fenomenologia da Percepção. $3^{\mathrm{a}}$ ed. - São Paulo: Martins Fontes, 2006.

MORAIS DA ROSA, Alexandre. Guia Compacto do Processo Penal conforme a Teoria dos Jogos. Florianópolis: Empório do Direito, 2016.

OST, François. O Tempo do Direito. Tradução Élcio Fernandes. São Paulo: Edusc, 2005.

PINTO, Felipe Martins. A Inquisição e o Sistema Inquisitório. Rev. Fac. Direito UFMG, Belo Horizonte, n. 56, p. 189-206, jan./jun. 2010

PRADO, Geraldo. Sistema acusatório. $3^{\mathrm{a}}$ ed. Rio de Janeiro: Lumen Juris, 2005.

QUEIROZ, Paulo de Sousa. Pode o juiz condenar sem que haja pedido de condenação? Empório do Direito.2016. Disponível em: <http://emporiododireito. com.br/pode-o-juiz-condenar-sem-que-haja-pedido-de-condenacao-por-paulode-souza-queiroz/\#_ftn5>. Acesso em: 13 mar. 2017.

VARGAS, Beatriz. O real da narrativa e a narrativa do real. In: BONATO, Gilson (org). Processo Penal, Constituição e Crítica. Rio de Janeiro: Lumen Juris, 2011. p. 139-148.

THEODORO JÚNIOR, Humberto.et al. Novo CPC: Fundamentos e sistematização. Rio de Janeiro: Forense, 2015.

TOURINHO FILHO, Fernando da Costa. Processo Penal, vol. 1. $34^{\mathrm{a}}$ ed. São Paulo: Saraiva, 2012. 


\section{Informações adicionais e declarações dos autores (integridade científica)}

Declaração de conflito de interesses (conflict of interest declaration): o autor confirma que não há conflitos de interesse na realização das pesquisas expostas e na redação deste artigo.

Declaração de autoria (declaration of authorship): todas e somente as pessoas que atendem os requisitos de autoria deste artigo estão listadas como autores. $\mathrm{O}$ autor se responsabiliza integralmente pelo conteúdo total deste artigo.

Declaração de ineditismo e originalidade (declaration of originality): assegura-se que o texto aqui publicado não foi divulgado anteriormente em outro meio e que futura republicação somente se realizará com a indicação expressa da referência desta publicação original; também atesta-se que não há plágio de terceiros ou autoplágio.

\section{Dados do processo editorial}

(http://www.ibraspp.com.br/revista/index.php/RBDPP/about/editorialPolicies)

- Recebido em: 13/05/2017

- Controle preliminar e verificação de plágio: 17/05/2017

- Avaliação 1: 24/05/2017

- Avaliação 2: 31/05/2017

- Avaliação 3: 06/06/2017

- Avaliação 4: 06/06/2017

- Decisão editorial preliminar: 06/06/2017

- Retorno rodada de correções 1: 18/07/2017

- Decisão editorial preliminar 2: 23/07/2017

- Retorno rodada de correções 2: 07/08/2017

- Decisão editorial final: 07/08/2017

\section{Equipe editorial envolvida}

- Editor-chefe: 1 (VGV)

- Revisores: 4 


\section{COMO CITAR ESTE ARTIGO:}

GARCIA, Rafael D. Verdade Real e a Impossibilidade de Condenação após Manifestação do Ministério Público por Absolvição. Revista Brasileira de Direito Processual Penal, Porto Alegre, vol. 3, n. 3, p. 1043-1070, set./dez. 2017. https://doi.org/10.22197/rbdpp.v3i3.81

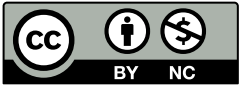

Esta obra está licenciada com uma Licença Creative Commons Atribuição-NãoComercial 4.0 Internacional. 